International Journal of Linguistics, Literature and Translation

ISSN: 2617-0299 (Online); ISSN: 2708-0099 (Print)

DOI: 10.32996/ijltt

Journal Homepage: www.al-kindipublisher.com/index.php/ijltt

\title{
Exploring Morphosyntax-related Semantic and Pragmatic Dimension Losses in Three English Translations of the Meanings of Sūrah AlKahf: A Comparative Pragmalinguistic Analytical Study
}

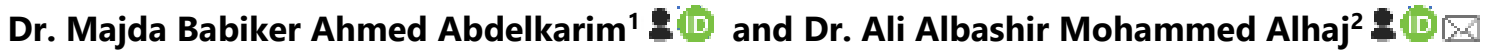 \\ ${ }^{1}$ Department of English, College of Science and Arts, King Khalid University, Ahad Rufaydah, Abha, Saudi Arabia \\ 2Department of English, College of Science and Arts, King Khalid University, Dhahran Aljanoub, Abha, Saudi Arabia
}

Corresponding Author: Dr. Ali Albashir Mohammed Alhaj, E-mail: dr_abomathani@yahoo.com

ARTICLE INFORMATION

Received: August 05, 2021

Accepted: September 17, 2021

Volume: 4

Issue: 9

DOI: $10.32996 / i j l t .2021 .4 .9 .14$

\section{KEYWORDS}

Morphosyntax; Sūrah AlKahf; Semantic; Pragmatic; translation; Pragmalinguistic; study

\section{ABSTRACT}

The current research paper explores some morphosyntax-related semantic and pragmatic dimension losses in three English translations of the meanings of Surrah AlKahf of Mohammed A.S Abdel- Hakeem, Mohammed M. Pickthall, and Mohammed Khan and Mohammed Taj Al-Din Al-Hilai . Also, the study aims at probing the reasons that lead to these semantic and pragmatic losses, either partial or complete. The two researchers utilized the qualitative descriptive paradigm, which is proper and apt to this study because the Holy Quran rendition is multiplex and cannot be deeply examined adopting another alternative research paradigm. Markedly, the qualitative descriptive paradigm is apt to analyze the data extracted from the three translations of Mohammed A.S Abdel- Hakeem, Mohammed M. Pickthall, and Mohammed Khan and Mohammed Taj Al-Din Al-Hilai Abdel of Surah AlKahf .The study indicated losses in renditions, tense, verbs, losses of consistency and morphosyntax grouping, and culture-specific terms. The study also revealed that the morphosyntax-related semantic and pragmatic dimension losses might lead to meaning losses, fixed expressions, idioms, or culture-specific terms. This study recommends that the translators of the Holy Quran in general and the translators of Surah AlKahf, notably, employ suitable translation strategies to decrease the morphosyntax-related semantic and pragmatic dimension losses in the translation of the Holy Quran.

\section{Introduction}

The issue of the Quranic translations into the English language and its accuracy and adequateness has always been obsessed with the minds of the Holy Quran translators, translation scholars and language receptors, and readers of Quranic renditions (Diniz, 2003, Abdelaal,2019, Khan,2008,). There are certain constraints and problems in rendering the Holy Quran into the English language, but recognition and rendition of the major Quranic terms are among the salient morphosyntactic and semantic problems. In this regard (Diniz.2003, Nida and Taber, 1982, Nord,1997) asserted the significance of tackling the translators' problems of the faithfulness of source text (ST). They stressed that rendition has always been more closely associated with adherence to the source text even though sometimes it evolves in a rendition that is not grasped for the considered aim.

The current paper research is a comparative critical study that intends at examining some morphosyntax-related semantic and pragmatic losses in three English translations of the meanings of Sūrah AlKahf; that is in three chosen English translations of Mohammed A.S Abdel- Hakeem,( the Qur'an: English translation with parallel Arabic text.2010) Mohammed M. Pickthall(The Weaning of the Glorious Qur'an,1930) (and Mohammed Khan and Mohammed Taj Al-Din Al-Hilai Interpretation of the Meaning of the Noble Qur'an,1993) (Alhaj, 2020).

\section{K C AL-KINDI CENTER R D FOR RESEARCH AND} Your gateway to world-class research

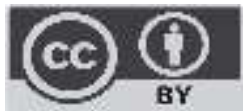

Published by Al-Kindi Center for Research and Development, London, United Kingdom. Copyright (c) the author(s). This open access article is distributed under a Creative Commons Attribution (CC-BY) 4.0 license 


\section{Objectives of the Study}

The study intends to:

a. Identify some morphosyntax-related semantic and pragmatic losses in translating the meaning of Sūrah AlKahf into English, and how these losses can be decreased?

b. What causes of the identified morphosyntactic losses in the three English translations of Mohammed A.S AbdelHakeem, Mohammed M. Pickthall, and Mohammed Khan and Mohammed Taj Al-Din Al-Hilai which lead to both semantic and pragmatic losses in rendering the meaning of Sūrah AlKahf into English ?

c. Probing the strategies employed by the three translators (Mohammed Abdel-Hakeem, Khan and Hilali, and Mohammed Pickthall) to render some chosen ayahs of Sūrah AlKahf into English?

\section{Questions of the Study}

To meet the aforementioned stated objectives of the study, the following research questions were drawn up:

1. What are the morphosyntactic losses that happen in translating the meaning of Surah AlKahf into English by the three translators (Mohammed Abdel-Hakeem, Khan and Hilali, and Mohammed Pickthall?

2. To what extent do these morphosyntactic losses cause semantic and pragmatic losses?

3. How can the identified losses be decreased?

4. Do the three translators employ good befitting translation strategies to secure interaction between the rendered texts and the Arabic socio-cultural context and recoup for these losses (if any)?

\section{Related Literature}

\subsection{Approaches of the Study: The pragmatic approach}

Pragmatics is the study of the problems and principles and the use of language in social interaction. (Thakur, p.1999).) Thus, the study of pragmatics aims to correlate it with the sense of lexemes that people use within their social milieu and select the appropriate words in a context.

According to Levinson (1993), as quoted in Abdullah (2015):

Pragmatics is the scientific study of the relation between the structure of a semiotic system (notable language) and its usage in context, and along with semantics, forms part of the general theory of meaning. Inside the theory of meaning, pragmatics particularly deals with inherent meanings, presumptions, and contextual interpretations: the method in which syntactical features of linguistic expressions operate on the background of presumption and inferences

The Philosophers who played a pivotal role in developing pragmatics are Grice, Austin, and Searle. The ideas of these Philosophers laid the theoretical basis for pragmatics, for example, Grice (1975/1998) introduces two major theories in pragmatics: theory of communication and theory of language use. (Alhaj, 2020,Thakur,1999). Searle made certain amendments and restrictions in the Theory of Speech Acts. Like Austin, Grice also gave a series of William James lectures at Harvard University in 1967. The ideas given out by Grice in these lectures were known as the Theory of Conversational Implicature. (Thakur, 1999, Siddiqui,2018).

Grice's mechanism of implicatures works in two distinct ways; First, speakers follow or observe the maxims in a direct way which brings about straightforward inferences: while uttering a sentence, the speaker is relevant, truthful, clear, and informative as the speaker concerns appropriate in the course of conversation. Levinson (1993, p.104) refers to these types of inference as a standard implicature.

The second type of conversational implicatures is generated by flouting or exploiting one of the maxims for specific communicative purposes: the speaker deliberately and overtly breaches one or more maxims for a hidden conversational motive to be communicated by an utterance (Hassan,1999). However, for the inferencing process to work, the speaker is assumed to be cooperative at some deeper level by following at least the co-operative principles that specify that if a conversation is to proceed rationally, it must consist of connected utterances. (Thakur, 1999. Hassan,1999). The other principle is the politeness principle, which not emphasizes the value of politeness in social interaction but also highlights the fact that what is considered very polite in one society may be less polite or utterly impolite in another society.

However, the key to understanding the communicative goals relies on what hearers need to infer the implicatures intended by the speaker. Grice $(1975 / 1998$, p.50) proposes that for the hearers to work out the conversational implicatures, they must rely on the following:

(1) The conventional meaning of the words used, together with the identity of any references that may be involved

(2) The co-operative principles and its maxims

(3) The context, linguistic or otherwise, of the utterance. 
(4) Other items of background knowledge

(5) The fact (or supposed fact) that all relevant items falling under the previous headings are available to both participants and both participants know or assume this to be the case.

According to Grice (1994), as quoted in Alhaj (2020): the subdivision of the general principle of CP are a set of maxims and submaxims of conversation which participants in a verbal interaction are mutually expected to observe.

These maxims are as follows :

\section{A. Quantity:}

1. Make your contribution as informative as is required (for the current purposes of the exchange).

2. Do not make your contribution more informative than is required

B. Quality: Try to make your true contribution one.

1. Do not say what you believe to be false.

2. Do not say that for which you lack adequate evidence.

\section{Relation: Be relevant.}

D. Manner: Be perspicuous.

1.Avoid obscurity of expression.

2. Avoid ambiguity.

3. Be brief (avoid unnecessary prolixity).

4. Be orderly

To conclude, as mentioned above, pragmatics deals with several maxims relevant to social interaction. The maxim of manner, for example, requires that the participants in a conversation be brief and orderly and avoid obscurity and ambiguity.

\section{Related Previous Studies}

Even though there is a colossal plethora of literature reviews on the renditions of the Holy Quran into the English language, very few research papers explored morphosyntax-related semantic and pragmatic dimension losses in English translations of the meanings of the Holy Quran.

Abdelaal and Rashid (2016) conducted a study exploring grammar-related semantic losses in the translation of the Holy Quran, with particular reference to Surah Al A'araf (The Heights). Moreover, the study revealed that grammatical losses contributed to semantic losses, which are mostly partial semantic losses of the connotative, affective, and emotive meanings. Also, Abdelaal and Rashid (2016, ibid, p,1) suggested that in their study, the translators of the Holy Quran should employ some appropriate, accurate, and adequate translation strategies to decrease the semantic losses in the rendition of the meaning of the Holy Quran into the English language.

In their turn, the same researchers, Abdelaal and Rashid (2015), conducted another study entitled, semantic loss in the Holy Qur'an Translation with special reference to Surah AI-Wāqi'ah (Chapter of The Event Inevitable). Moreover, the study showed that the frequent partial and complete semantic loss of meanings mostly due to mistranslations, semantic complexity of the vocabularies, and culture.

Mahmoud (2008) addressed how cultural and pragmastylistic aspects affect the rendering of sūrat Al-Nās into the English language. The study attempted to identify the relationship between pragmatic coherence and stylistic variations at the level of the source text and how they affect the rendition of the Holy Quran in general and Surat Al-Nas in particular. The study also underscores the need for Qur' ānic knowledge to keep away from the impediments in rendering sacred Quranic texts into the English language.

Baker (2011) and Abdul-Raof (2010) agree that the Holy Quran is unrenderable and that any rendition is a form of explication. In her turn, Baker (2011, p.277) states that "any attempt at translating the Qur'an is essentially a form of exegesis, or at least is based on an understanding of the text and consequently projects a certain point of view: hence the preference it is given to Muslim as opposed to non-Muslim translators". In his turn, Abdul-Raof (2010, p.1) also states tbat "Qur'anic expressions and structures are Qur'an bound and cannot be reproduced equivalently to the original in terms of structure, the mystical effect on the reader, and intentionality of source text". 
Alhaj (2020) carried out a study entitled "A Pragma- Stylo -Semantic Analysis of Three Translations of the Meanings of Surratt Al-Saffat into English: A Comparative Linguistic" Study. The study aimed at aims at exploring the pragma- stylo-semantic obstacles encountered by the translators of the meaning of the Holy Qur'an into English and the challenging task in translating Surah Al-Saffat into English. The study also showed that literal translation poses problems on different levels. These are; words, idioms, style, and culture.

The present study differs from all the previous studies on semantic and pragmatic meaning losses in the translation of the Holy Qur'ān not only in its scope but also in an endeavor to explore several linguistic problems, for example, some morphosyntaxrelated semantic and pragmatic dimension losses to tackle the rich phenomenon of meaning losses in the translation of the Holy Qur'ān into the English language.

\section{Research Methodology}

This part of the study aims to highlight the research method employed by the three researchers in collecting data of the current research paper.

\subsection{Method}

\section{Research paradigm}

There are two mains paradigms of research, quantitative and qualitative

This research paper squares with the interpretive paradigm of a latter. The qualitative research paradigm is proper and apt to this study because the Holy Quran rendition is multiplex and cannot be deeply examined utilizing another alternative research paradigm. Creswell and Clark (2007) stated that a qualitative research paradigm is suitable when a multiplex inductee grasp of a subject is probed and when quantitative measurements and analyses do not fit the research problem. (Alhaj,2020, Abdelwali, 2010).

\subsection{Sampling of the Study}

The current research paper intends to examine some morphosyntax-related semantic and pragmatic dimension losses in three English translations of the meanings of Sūrah AlKahf. The purposive samplings of the current study were taken out from English translations of the meanings of Sūrah AlKahf rendered by Mohammed A.S Abdel- Hakeem, Mohammed M. Pickthall, and Mohammed Khan and Mohammed Taj Al-Din Al-Hilai.

This study used purposive sampling for this study, as it is considered suitable for the analytical descriptive qualitative method. (5 examples were purposefully extracted from Sürah AlKahf). In this regard, the two researchers painstakingly chose the samples that contained morphosyntax-related semantic and pragmatic dimension losses in these Holy Qur'anic (verses) Ayahs meaning take place in English rendition of the Holy Quran

\subsection{Data Analysis}

To find out the morphosyntax-related semantic and pragmatic dimension losses in these Holy Qur'anic (verses) Ayahs., the two researchers used comparative analysis to analyze the collected data and then read the original texts of Qur'anic (verses) ayahs in Arabic and compare them to their English translation version.

\subsection{Procedures}

The most essential research instrument is reading, analyzing, and comparing the translated text of selected ayahs of Sūrah AlKahf rendered by Mohammed A.S Abdel- Hakeem, Mohammed M. Pickthall, and Mohammed Khan and Mohammed Taj Al-Din Al-Hilai.

This study is comprehensive and wide-ranging. Three renditions of the meanings of Sūrah AlKahf have been analyzed and identified by the two researchers to find ayahs containing morphosyntax-related semantic and pragmatic dimension losses. When analyzing the three translations, the two researchers followed the following procedures.

(i) First of all, the two researchers obtained the three translations of the meaning of the Holy Quran of Mohammed AbdelHakeem, Khan and Hilali, and Mohammed Pickthal.

(ii) studying each ayah (verse) to find ayahs containing morphosyntax-related semantic and pragmatic dimension losses.

(ii) analyzing Mohammed Abdel-Hakeem, Khan and Hilali, and Mohammed Pickthall's translations and identifying their appropriateness adequacy in rendering ayahs containing morphosyntax-related semantic and pragmatic dimension losses and then giving comments on the three translations. 


\title{
6.5 Research Instrument
}

The research instrument is very paramount to get the finding of a study. It is a set of methods that are employed to collect the data. The two researchers act as the instrument of the study. As Cresswell (1994, p.145) opines, qualitative research is the key instrument for gathering and analyzing data. Besides that, the two researchers spend a great deal of time in reading, probing, identifying, and comparing morphosyntax-related semantic and pragmatic dimension losses in three English translations of Sūrah AlKahf rendered by Mohammed Abdel-Hakeem, Khan and Hilali, and Mohammed Pickthall. Then the data will be analyzed by the two researchers in conformity with the problem of the current study.

\section{Results and Discussions}

Examples of Comparative Linguistic Analysis of Some Selected Translated (Verses) Ayahs of Sūrah AlKahf into the English language

\section{Example 1}

Source Surrah " AlKahf ,The Cave ", ayah, verse 1

ST:الْحَمْدُ لِلَّهِ الَّذِي أَنزَلَ عَلَنى عَبْدِهِ الْكِتَابَ وَلَلمْ يَجْعَل لَّهُ عِوَجَا(1)

Transliteration: Ihamdu lillaahil lazeee anzala 'alaa 'abdihil kitaaba wa lam yaj'al lahoo 'iwajaa

\section{Target Text:}

(1) Abdel Haleem:" Praise be to God who sent down the Scripture to His servant and made it unerringly straight ".

(2) Khan and Al-Hilali: "All the praises and thanks are Allah's Who has sent down to His slave (Mohammed (PBUH) the Book (The Quran) and has not placed therein any crookedness ".

(3) Pickthall:" Praise be to Allah Who Hath revealed the Scripture unto his Slave and hath not placed therein any crookedness".

\section{Discussion}

The Meaning of the Ayah

It is stated in the Hadith that the Messenger of Allah (PBUH) said" Whoever memorizes ten ayahs (verses) from the beginning of Surat Al-Khaf will be protected from the Dajjal (the Imposter) ".Imam Muslim narrates this Hadith. Hadith's wording narrated by Imam Muslim is "Whoever recites the last ten verses of Surat Al-Khaf will be protected from the Dajjal (the Imposter)".The Hadith also recorded that the Messenger of Allah(PBUH) said: "Whoever recites Surat Al-Khaf as it was revealed, it will illuminate him with light from one Friday to the next. "This Hadith is recorded by Al-Hakim who said" This is an authentically transmitted Hadith." (Tafiser Ibn Kathir, Volume (2) p.1182).

\begin{abstract}
"All the praises and "All the praises and thanks are Allah". meaning, this in truth is a good attribute which is acknowledged for (Allah) the Almighty. It is not known whether this is stated only to tell the human beings about this so as they be therein believers or that it is meant to be praising and glorifying Allah or each alone. These indeed are options the best of which is the third. "Who has sent down to His slave" meaning, Mohammed (PBUH)." The Book" meaning, The Holy Quran. (Tafsir AlJalalalyn,2010, Volume, 1,842." And has not placed therein any crookedness", meaning, i.e., it includes nothing inexplicit, deviated or confusing. Rather, Allah made it well-versed in a balanced and straightforward manner, all guiding to the Straight Path. " (Tafiser Ibn Kathir,2002, Volume (2) p.1182).
\end{abstract}

\section{Evaluation of the Translation}

The lexeme alhamdu (al-ḥamduُ الْحَمْد (is a nominative masculine noun. It has been rendered into a common noun (praise) by Abdel Haleem" Praise be to God who sent down the Scripture to His servant and made it unerringly straight "and Pickthall:" Praise be to Allah Who Hath revealed the Scripture unto His Slave and hath not placed therein any crookedness ", whereas the same noun is rendered by Khan and Al-Hilali into a noun phrase "All the praises and thanks are Allah's "It seems that a try has

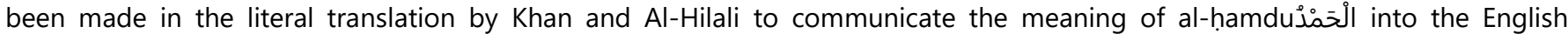
language. Also, Hilali \& Khan combining their translation with an explanatory note, telling the receptors directly about the intended meaning of the ayah at hand (a translation method that) Khan and Hilali's rendering ranks the best because they clarified the ambiguity by adding (Mohammed (PBUH) after the phrase (His salve), and (The Quran) after (The Book).

The noun lillahi (is) for Allah consists of " proposition(J) li and proper genitive noun (لَّ) lahi. This noun was rendered into God by Abdel Haleem and Allah by Pickthall, Khan, and Al-Hilali. Abdel-Haleem renders the word (الله)to (God) which is not denotatively or connotatively equivalent to (Allah(الله for many reasons. First, لله lis a proper noun referring to the Name of the 
Lord and names are not rendered into other language but transliterated. (النقحرة.( Second, (God) ( with a capital G) denotes ( (الإله (in Arabic which is used in other ayahs, therefore(God) should be used as an equivalent to the word (الإله (Third, the word الله/(is a unique Arabic linguistic form, unlike the English lexeme God; hence, God, by no means, echoes the Arabic word Allah(الله).

Contrary to the traditional word "God", Pickthall, Khan, and Al-Hilali use the real name "Allah" which some may appreciate and criticise by others in the English community. However, contextually it is quite appropriate (Khan,2008, p.133). Moreover, these renditions may ensue into a pragmatic loss of culture-specific terms.

Abdul-Haleem 's rendering of ( عَبْدِ His servant) suffers from the effects of literal translation which is often also culturally foreignizing and also his rendering is not connotatively equivalent because the element (His Servant) results in a vague meaning. Consequently, a reader who has no previous knowledge of the Quran or Islam is likely to fail to understand (His servant). The Term (His slave) in The Holy Quran refers to the Prophet Mohammed (PBUH). This reference is very clear to Muslims because they are aware of the story and because This expression occurs on several occasions in the Quran. By contrast, a non-Muslim reader will not be able to understand to whom the term servant refers.

To clarify this connotative meaning, Khan and Hilali add information and point to Mohammed (PBUH) in their rendering to clarify the vague meaning and this is why their renderings take (strong connotation) in semantic connotation) and AbdulHaleem's rendering takes (mild connotation). Moreover, the word' servant' does not throw back the aspired meanings of the text as per the context. However, this rendering may result in the morphosyntax-related pragmatic losses of the referential versatileness of the Qur'anic words.

\section{Example 2}

Source Surrah "AlKahf, The Cave", ayah, verse 3

ST: مَاكِيْينَ فِيه أَبَدَ(3)

Transliteration: Maakiseena feehi abadaa

\section{Target Text:}

(4) Abdel Haleem:" That they will always enjoy "

(5) Khan and Al-Hilali: "They shall abide therein forever"

(6) Pickthall:" Wherein they will abide therein forever."

\section{Discussion}

\section{The Meaning of the Ayah}

"They shall abide therein forever" meaning, they will eternally dwell in the reward that Allah will bestow to them. The Paradise wherein they will abide " forever" i.e., their reward will be everlasting, having no end or removal. ( Tafiser Ibn Kathir, Volume(2) p.1183) .

\section{Evaluation of the Translation}

Abdel Haleem omitted the emphasizing adverb" آَبَدً abadan forever" which affect the intensity of the Message. However, these morphosyntax-related semantic and pragmatic changes may result in the pragmatic loss of meanings of the ayah" Maakiseena feehi abadaa.(3) مَاكِثِينَ فِيِيه أَبَدًا (3) omission of the adverb" forever" that has been done by Abdel Haleem may confuse an average reader in its semantic context. The use of the adverb" forever" by Khan, Al-Hilali ' they shall abide therein forever' 'as well as Pickthall" wherein they will abide forever" is appropriate translating in the co-text or linguistic context, which maintains cohesion and promises more vivid and efficient communication and comprehension. Moreover, the omission of the verb" to abide " that has been done by Abdel Haleem led to a pragmatic loss in the ayah. It is clearly illustrated through the co-text analysis that Mohammed Abdel-Hakeem, Khan and Hilali, and Mohammed Pickthall are not on the same wavelength in terms of their renditions of Maakiseena مَاكِيَين(They will) abide. Abdel Haleem has dropped the lexeme in his rendering" that they will always enjoy "; hence his translation is out of context because it has syntactic ambiguity and syntactic expansion for ellipsis for both " the adverb, forever", which has been rendered into English verbal to-infinitive and future indefinite tense" they shall abide", and "will abide" respectively by Khan and Hilali, and Mohammed Pickthall. However, these syntactic, pragmatic, and semantic changes may result in morphosyntax-related semantic-pragmatic losses of consistency and morphosyntax grouping. 


\section{Example 3}

Source Surrah " AlKahf, The Cave", ayah, verse (9)

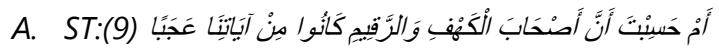

Transliteration: Am hasibta anna Ashaabal Kahfi war Raqeemi kaanoo min Aayaatinaa 'ajabaa Target Text:

(7) Abdel Haleem: [ Prophet], do you find the Companion in the Cave and Al-Raqim so wondrous, among all Our other signs?

(8) Khan and Al-Hilali: Do you think that the people of the cave and the Inscription (news of the names of the People of the Cave) were a wonder among Our signs?

(9) Pickthall: "Or deemest thou that the People of the Cave and the Inscription are a wonder among Our portents?

\section{Discussion}

\section{The Meaning of the Ayah}

Here in this ayah(verse), Allah Almighty begins narrating the story of the people of the Cave (Al-Kahf) in brief and general terms , then He explains it in more detail saying:" Do you think" meaning, ' O Muhammad, do you think (that the people of the Cave and Al-Raqim were a wonder among Our Signs?,That is Allah says, 'O Muhammed, their case was not something stunning when compared to Our might and ability, due to the fact that the creation of the heavens and the earth and the alternation of night and day, My subjugating of the sun and the moon and the heavenly bodies and the other ever stunning signs would testify to the might of Allah, all affirming that Allah is the All-Able to do whatever He wills, and that nothing even more amazing than the news of people of the Cave would ever be beyond the scope of Allah, the Almighty, For, amongst Our signs are there that which are even more stunning than this ' AL-Akahf refers to a Cave in a mountain wherein the young men sought refuge. AlRaqim refers to a valley which is near Aylah, or that it is the name of the valley, or that it refers to their buildings, or that is the valley wherein their cave is located, or the town, or that it is a tablet of stone wherein people sculptured the story of the people of the Cave, then they placed it at the entrance of the Cave. Abdulrahman Ibn Aslam said:"AR-Raqim is the book. Then he recited (A Register inscribed). This indeed is the best the verse indicates, according to Ibn Jarir. ( Tafiser Ibn Kathir, Volume(2) p.1184)

\section{Evaluation of the Translation}

In translating this Ayah, the three translators utilized punctuations, for example, interrogation point(?). This corresponds to the Arabic text of the Holy Quran. The three translators used the interrogation mark(?) has been used by the three translators to maintains syntactic context and maintain contextual spread through the rendition of the Ayah, which meets the demand of the receptor of the Quranic Message (Khan,2008, p.133). The clause (do you find) by Abdel Haleem at the beginning of this verse is confusing for the Target Language receptor. In this way, sometimes interlinear translation frustrates the common reader. (Ibid, p. 133).

The Arabic word وَالرَّقِيم wal-raqīmi has been retained and transliterated (النقحرة)into Al-Raqim which maintains the context but maybe not easy for the Target Language receptor because it identified as an element of pragmatic losses.

The Arabic word-raqimi has been rendered into "the Inscription" by Pickthall, khan, and Al-Hilali who used the couplet translation method (combining two procedures "literal translation + explanation). These types of words put enormous problems to translators of the Holy Quran and confuse the target language receptors and readers in the procedure of mastery of the Quranic Message if not embodied in rendition adequately. Hence, the translators of the Holy Quran The translators should consult the main exegetical work such as Al-Zamakhshri(Linguistic); Al-Razi( philosophical); Al-Tabard and Al-Suyuti( intertextual); Al-Qurtubi( jurisprudence), and AlTha'alibi( historical). This type of situation may result into the morphosyntax related semantic and pragmatic losses of contextual meaning.

\section{Example 4}

Source Surrah " AlKahf, The Cave ", ayah, verse 11.

ST:(11) فَضَرَبْنَا عَلَنَ آذَانِهِمْ فِي الْكَهْفِ سِنِينَ عَدَدَا

Transliteration: Fadarabnaa 'alaaa aazaanihim fil Kahfi seneena 'adadaa 


\section{Target Text:}

(1) Abdel Haleem: "We sealed their ears [ with sleep in the Cave for years] ".

(2) Khan and Al-Hilali: " therefore, We covered, their (sense of) hearing (causing them to in deep sleep) in the Cave for several years.

(3) Pickthall:" Then We sealed up their hearing in the Cave for several years"

\section{Discussion}

\section{The Meaning of the Ayah}

"We sealed their ears [ with sleep in the Cave for years] " meaning, that is, 'We (Allah) the Almighty caused them to sleep for many years when they entered the cave. ( Tafiser Ibn Kathir, Volume(2) p.1186)

\section{Evaluation of the Translation}

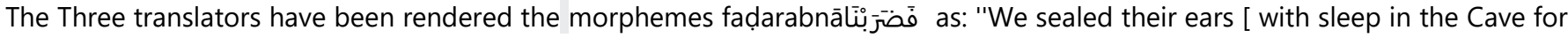
years" by Abdel Haleem. Then, "therefore, We covered, their (sense of) hearing (causing them to in deep sleep) in the Cave for several years "by Khan and Al-Hilali and so" Then We sealed up their hearing in the Cave for several years" Pickthall, respectively. Markedly, the three translators successfully utilize the same past tense (sealed, covered, sealed) but with different morphosyntactic grouping selections in their renditions. Moreover, the Quranic Arabic present perfect tense(verb) has been rendered into past indefinite tense of the English language. The differences in morphosyntactic selection do not appear to give back the contextual spread of meaning throughout the rendition of the Surah. However, these renditions may result in the pragmatic loss of textual meaning.

It has been said earlier that rendering the Quranic idioms and cultural fixed expressions is a very difficult and arduous task, due to many factors such as the lack of the target English text culture, and the unfamiliarity with the strategies of translation employed to tackle such the Quranic idioms and cultural fixed expressions this applies to rendering idioms and fixed expressions in the Holy Quran in general in Surah AlKahf in particular. The Quranic Idioms or fixed expressions must be interpreted before rendering the sense into the target text., regrettably, renditions of the meaning of the Holy Quran are not free from literal rendition and word-for-word translation as well as translationese. Accordingly, some translators of the Holy Quran went wrong to render the Quranic idioms and fixed cultural expressions. This poses special challenges for the translator of the Holy Qur'an since an over occupation with lexical, semantic, and syntactic equivalence and fidelity could yield the opposite result - a loss in

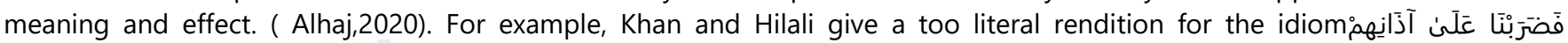
Fadarabnaa 'alaaa aazaanihim (We covered, their (sense of) hearing). This literal translation makes the meaning of the ayah incomprehensible because it affects communication and comprehension and causes confusion in its semantic context. This Qur'anic Arabic idiom means that Allah, Almighty has sealed their ears, so they do not hear anything while they were sleeping in the cave" (Abdul-Raof 2010,.p 31). Therefore, this rendition may result in the pragmatic loss of culture-specific terms To conclude, the co-text, the translators of the holy Quran consider the receptor's suppositions and his understating problems; hence the general style is rather close to the idiom of the target text throughout the rendition of the ayah.

\section{Example 5}

Source Surrah " AlKahf, The Cave ", ayah, verse 13.

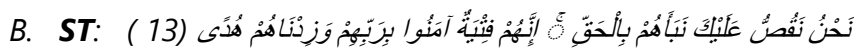

Transliteration: Nahnu naqussu 'alaika naba ahum bilhaqq; innahum fityatun aamanoo bi Rabbihim wa zidnaahum hudaa

\section{Target Text:}

(4) Abdel Haleem:'[ Prophet], We shall tell you their story as it was. They were young men who believed in their Lord and We gave them more guidance".

(5) Khan and Al-Hilali: "We narrate to you (O. Mummed (PBUH)) their story with truth: Truly, they were young men who believed in their Lord (Allah) and We increased them in guidance."

(6) Pickthall:" We narrate unto thee their story with truth. Lo! They were young men who believed in their Lord, and We increased them in guidance " 


\section{Discussion}

\section{The Meaning of the Ayah}

The meaning of this ayah is: from Allah, the Almighty starts to explain the story of the people of the Cave in detail. Allah, the Almighty states that they were young men and that they were more inclined to accept the truth and were of more liability to be righteously guided than the aged who had become stubbornly obsessed in the religion of falsehood. Hence, of most of those who responded positively to Allah (SWT) and His Messenger, Mohammed (PBUH) was from among the youth. Regarding the aged people of Quraysh, most of them were stubbornly adhering to their (false) religion, and only a few of them embraced Islam. (And We increased them in guidance) Having this ayah together with other similar ones, several scholars, such as Imam Ibn Kathir and others, elicited that one's faith may increase, all the while varying in degrees, and that it may fluctuate in decrease well.

Although this ayah states) إنَّهُمْ فِتْيَةُ آمَنْوا بِرَبِهِمْ (it ends with وَزَدْنَاهُمْ هُدَدى if the young men mentioned here are already on huda, since they have accepted Allah's huda and followed it, then in what way would their huda be increased. According to AlAlusi(1980, p.89), huda here means to keep them steadfast on their belief in Allah(SWT) and to grant them the success of performing good deeds. Once more" guidance" is a general expression of huda.

\section{Evaluation of the Translation}

The lexeme[prophet] has been utilized only once by Abdel Haleem in the translated version of this ayah and that too in the parenthetic expansion. Hence, Abdel Haleem's rendering bears more communication as compared to the renderings of Khan and Al-Hilali: and Pickthall.

The three translators' renderings "Lord" " is less appropriated as compared to the lexical choice " Rabb, Sustainer" by other translators of the Holy Quran. The word ' Lord" has worldly attributes whereas the words" Rabb and Sustainers " maintain divinity. In conformity with the tense of the Arabic verb, نَقُصٌٌ naqușuit may be rendered into present tense as rendered by Khan and Al-Hilali" We narrate to you (O. Mummed (PBUH)) their story with truth: Truly, they were young men who believed in their Lord (Allah) and We increased them in Guidance" and Pickthall:" We narrate unto thee their story with truth. Lo! They were young men who believed in their Lord, and We increased them in guidance and future tense as rendered by Abdel Haleem:'[ Prophet], We shall tell you their story as it was. They were young men who believed in their Lord and We gave them more guidance" as regarded syntactically and contextually proper by the translators of the Holy Quran. However, the selections of tense in the rendition do not he opt to the imperfect verb. Hence, these renditions by the three translators may result in the pragmatic loss of tense potentialities.

\section{Conclusion}

This research paper has concentrated on exploring the morphosyntax-related semantic and pragmatic dimension losses in three English translations of the meanings of the Holy Quran by Mohammed A.S Abdel- Hakeem, Mohammed M. Pickthall, and Mohammed Khan and Mohammed Taj Al-Din Al-Hilal, with special reference to Surah AlKahf, The Cave, and level the distinct types of syntactic losses which may lead to semantic and pragmatic losses. The results of the current research paper indicated that losses happen in the renditions, tense, verbs, losses of consistency and morphosyntax grouping, and culture-specific terms. Moreover, some of these morphosyntax-related semantic and pragmatic dimension losses are avoidable which could have been decreased.

\section{Acknowledgements}

The two authors extend their appreciation to the Deanship of Scientific Research at King Khalid University for funding this work through General Research Project under grant number [G.R.P,1/42/No 276, YP,1443, AH/2021CE]

\section{References}

[1] Abdelwali, M. (2007). The Loss in the Translation of the Qur'an. Translation Journal, 11(2), 1-8.

[2] Abdelaal, N. M., \& Md Rashid, S. (2016). Grammar-related semantic losses in the translation of the Holy Quran, with special reference to Surah Al A'araf (The Heights). SAGE Open, 6(3), 2158244016661750.

[3] Abdelaal, N. M., \& Md Rashid, S. (2015). Semantic loss in the Holy Qur'an translation with special reference to Surah Al-W a qiAAa (Chapter of The Event Inevitable). SAGE Open, 5(4), 2158244015605880.

[4] Abdullah, M. (2015). Deixis: A Pragmatics Analysis. Language in India, 15(12), 3-9.

[5] Abdul-Raof, H. (2013). Qur'an translation: Discourse, texture and exegesis. Routledge.

[6] Alhaj, A. A. M. (2020). A Pragma-Stylo-Semanitc Analysis of Three Translations of the Meanings of Surratt Al-Saffat into English: A Comparative Linguistic Study. International Journal of Applied Linguistics and English Literature, 9(2), 82-91.

[7] Mesfer, A. A. M. A. D., \& Alwadai, A. M. Ideo-Cultural and Lexical Challenges Encountered in Translating Qur'anic Metaphoric Expression into English: With Reference to Three Translations of the Meaning of the Holy Quran. Journal of Literature, Languages and Linguistics, 53, 46-59. 
[8] Alhaj, A. A. M., \& Alwadai, M. A. M. (2019). Constrains of Rendering Some Selected Qur'anic Verses (Āyahs) into English: A Socio-rhetorical Interpretation. International Journal of Linguistics, Literature and Translation, 2(5), 102-117.

[9] AlQurtubi, M. (2004). Al JamAA liahkam al Qur'an (Tafsir Al Qurtubi). Cairo, Egypt: Dar Al-Fikr.

[10] Alusi, M. (1980). Ruh al-Maani, Bayrut. Lebanon

[11] Al-ssyuti, J. (2008). Muzhir fi Olum Allughah wannwAAaha [The luminous work concerning the sciences of language and its subfields] (3rd ed.). Cairo, Egypt: Dar Al-Tturath.

[12] Alt-Tabari, M. (2003). JaamiAA Al-Bayaan AAn Ta'weel Ayil Qur'an [The commentary on the Quran]. Cairo, Egypt: Al-Halabi. Dar Al- Maref.

[13] Al-zzamakhshari, A. Q. (1407 A.H). The Revealer of Facts of Obscure Revelations. Al Kashshaf AAn haqaiq ghawamed attanzeel. (Unveiling the Facts about the Revealed Quran Secrets). Cairo, Egypt: Arabic Publishing House.

[14] Baker, M. (2010). Critical readings in translation studies. Abingdon, Oxon. New York. Routledge

[15] Catford, C. (1990). A Linguistic Theory of Translation: An essay on applied linguistics. London: Oxford University Press.

[16] Cresswell, S. (1994). Content Analysis: Concepts, Methods, and Applications. Nurse Researcher, 4(3), 5-16.

[17] Grice, H. P. (1994). Studies in the ways of words. Harvard University Press.

[18] Ibn Kathir, H. D. (2002). tafsiru alQur'ani alkarim [Commentary on the Quran]. Beirut, Lebanon: Maktabat Nour Al'ilmijja

[19] Levinson, C. (1993). Pragmatics. Cambridge: Cambridge University Press

[20] Mahmoud, A. (2008). Cultural and pragmastylistic factors influencing translating surat Annās of the glorious Qur'an into English. J. Res. (H. Sc.), $22(6), 18491884$

[21] Pickthall, M. (1969). The meaning of the glorious Koran. New York, NY: The New American Library of World Literature.

[22] Khan, M.E.(2008) Approximation of the Meaning of the Holy Quran: A linguistic analysis. Oxford: B. Blackwell

[23] Thakur, D. (1999). Linguistics simplified Semantics. New Delhi: Bharati Bhawan publishers.

[24] Searle, John R. (1969). Speech acts. An essay in the philosophy of language. Cambridge: University Press

[25] Siddiqui,Ali(2018). The Principal features of English Pragmatics in Applied linguistics. Advances in Language and Literary Studies under CC license(https://creativecommons.org/licenses/by/4.0/)nhttp://dx.doi.org/10.7575/aiac.alls.v.9n.2p.77.

[26] Yule, G. (1998) Pragmatics. Oxford: University Press 